\title{
KUNTOUTUS INTEGROI SOTEN
}

\section{Kuntoutus on sote-integraation lippulaiva}

Kuntoutus on ihmisten hyvinvointiin, terveyteen, työ- ja toimintakykyyn sekä osallisuuteen monimuotoisesti vaikuttava yhteiskunnallinen investointi. Sillä on laajat yhteisövaikutukset. Työkyvyn aleneminen aiheuttaa seurauksia työyhteisöön ja lopulta organisaation menestymiseen. Myös syrjäytyminen on usein yhteisöllistä. Osallisuuden kokemukset syntyvät tai jäävät syntymättä erilaisissa ryhmissä ja yhteisöissä.

Kuntoutus leikkaa läpi yhteiskuntapolitiikan sektoreiden. Juuri siksi kuntoutus voi toimia sektorien integraattorina. Se voi liimata yhteen sosiaalipoliittiset, työvoimahallinnolliset, erikoissairaanhoitoon ja perusterveydenhuoltoon sekä kasvatukseen liittyvät näkökulmat. Tällä otteella päästään lopputuloksiin, jotka tyydyttävät niin kuntoutujaa kuin palveluiden järjestäjää ja tuottajaakin.

Kuntoutussäätiön ja Varman toteuttamassa kuntoutuskyselyssä haluttiin selvittää kuntoutusalan ammattilaisten, päättäjien, palvelutuottajien ja kehittäjien näkemyksiä kuntoutuksesta, sen polttavimmista kehittämistarpeista ja mahdollisuuksista kiinnostavassa murroskohdassa. Kontekstualisoimme kyselyn suomalaisen hyvinvointiyhteiskunnan perusteita rajusti muuttavaan uudistukseen, sosiaali- ja terveydenhuollon järjestelmämuutokseen. On ymmärrettävää ja loogista, että sote-uudistukseen ladataan myös kuntoutuksen kannalta runsaasti odotuksia. Tämä näkyi myös kuntoutuskyselymme vastauksissa.

Sote-uudistuksen kivijalka on integraatio. Sosiaalihuollon, perusterveydenhuollon ja erikoissairaanhoidon integraation oletetaan $\mathrm{ku}-$ rovan umpeen kolmen miljardin euron kestävyysvajetta ja tuottavan ennennäkemättömiä asiakashyötyjä. Integraation oletetut hyödyt ja sen taustalla olevat tarpeet olivat vahvasti esillä myös kyselymme tuloksissa.

Paul Lillrankin ym:iden (2016) tuoreessa pamfletissa "Seitsemän syytä sairauteen. Miksi terveydenhuolto ei toimi" todetaan, ettei hallinnon integraatio sinänsä takaa mitään. On aivan mahdollista, että laatikkoleikkien puolesta yhdistetyssä järjestelmässä siilorajat jatkuvat kuten tähänkin asti.

Avain muutokseen ja todellisiin asiakashyötyihin on hoitopolkujen integroinnissa. Jotta tämä onnistuu, tarvitaan kannusteita, valtaa ja johtajuutta murtaa nykyisiä siilorakenteita sekä eri ammattiryhmien keskinäistä kanssakäymistä asiakashyödyn maksimoimiseksi.

Kuntoutus kaikkinensa on integraatiolaji. Juuri kuntoutuksessa perusterveydenhuollon ja erikoissairaanhoidon sekä sosiaalihuollon integrointi tuottaa asiakashyödyt ja isot säästöt hyvinvointimenoissa. Koordinoinnilla ei saavuteta mitään. Kuntoutusjärjestelmän pirstaleisuus ei sillä korjaudu. Kuntoutus voi olla soteuudistuksen lippulaiva - sektori, joka osoittaa, miten integraatio käytännössä parhaiten ja tehokkaimmin toteutetaan.

Varman ja Kuntoutussäätiön toteuttamassa kuntoutuskyselyssä hoitopolkujen ja -prosessien virtaviivaistaminen ja riittävän varhainen kuntoutustarpeen tunnistaminen nousivat kriittisiksi parantamisalueiksi kuntoutuksessa. Kuntoutuksessa ratkaisun avaimet löytyvät moniammatillisuudesta ja moniammatillista tiimeistä - integroinnin ytimestä. Sinänsä ei ole merkitystä, kuuluvatko tiimin jäsenet eri hallinnollisiin yksiköihin, siiloihin, jos he kykenevät ja haluavat rakentaa yhteisen ymmärryksen asiakkaan kuntoutumisesta. Yksilöllisen palveluohjauksen tai case manageroinnin periaate - toteutettuna uudella otteella niin, että rakennetaan kokoamalla palveluja asiakkaalle eikä vain ohjata häntä olemassa oleviin 
palveluihin - voisi toimia missä tahansa kuntoutujaryhmässä, myös silloin, kun kärkenä on sosiaalinen osattomuus. Tällaisessa palveluohjauksessa asiakkaan parhaaksi rakennetaan paras mahdollinen integroitu ymmärrys kuntoutuksen tavoitteista yhdessä asiakkaan kanssa.

\section{Kuntoutuksen sisällöt edellä}

Kuntoutussäätiön ja Varman toteuttaman kyselyn mukaan päättäjät eivät ole kovin kiinnostuneita kuntoutuksesta. Kuntoutusalan toimijat arvioivat myös heidän tiedon tasonsa alhaiseksi. On kummallista, että kuntoutusalan ammattilaiset eivät pidä itseään tärkeinä päättäjien silmissä. Sipilän hallituksen ohjelmassa kuntoutukselle annetaan paljon enemmän sijaa, merkitystä ja mahdollisuuksia kuin aikoihin. Eikö kuntoutusala osaa käyttää näitä mahdollisuuksia hyväkseen?

Onko niin, että kuntoutuskenttä hajoaa omiin kuppikuntiinsa, eikä yhteisiä viestejä saada riittävästi välitettyä eteenpäin päättäjille? Estääkö mantra "kuntoutusjärjestelmä ei toimi" järkevän uudistamisen ja tulevaisuudenkuvat? Kun sote-uudistus helposti jää rakennekeskusteluksi, kannattaisiko kuntoutusta nostaa rakenteiden sijaan sisältöinä esille?

Mielestäni kuntoutuksen näkyväksi tekeminen kannattaa tehdä nimenomaan sisältöjen kautta. Miten kuntoutus tukee päihdeongelmaista äitiä ja perhettä, miten pitkäaikaistyötön ja oppimisvaikeuksista kärsivä saadaan työllistymään kuntouttavan työn keinoin? Miten vaikeavammaisten liikuntaharrastukset yhdistettynä muuhun kuntoutukseen saavat heidät kiinnittymään yhteisöihin ja yhteiskuntaan?

Kun kuntoutuksen resurssit ovat pirstaleina, integraatiohyödyt ovat kuntoutuksessa mahdollista saada helposti aikaan. Kuntoutus integroi soten hyödyt.

\section{Kuntoutuksen innovaatiot}

Sosiaali- ja terveydenhuolto ja työllistäminen tarvitsevat uudistamista ja innovaatioita. Kyselymme tulosten mukaan asiakasymmärrys ja vuoropuhelu ammattilaisten ja kuntoutuja-asiakkaiden kesken ruokkivat parhaiten uudistu- misherkkyyttä ja kykyä saada aikaan uusia ideoita ja toimintamalleja.

Kuntoutuksessa etäkuntoutus tai avokuntoutus muuttuvat ajasta ja paikasta riippumattomaksi kuntoutukseksi, jossa kuntoutuspalvelun käyttäjästä tulee samalla aktiivinen palvelutuottaja. Ihminen ei enää ole "etänä" omasta elämästään, kuntoutuksessa. Kuntoutus tulee luontevaksi osaksi kaikkeen siihen, mitä arjessa teemme - helposti, asiakaslähtöisesti ja kustannustehokkaasti. Maailmalla tarjolla olevat 160 000 terveysteknologista applikaatiota tekevät tämän jo nyt mahdolliseksi. Kehittämisen sijaan kyse on käyttöönotosta ja soveltamisalueiden tunnistamisesta.

Erityisryhmille ja erityistarpeisiin tarvitaan epäilemättä jatkossakin jonkin verran laitoskuntoutusta ja fyysisiä tiloja. Ihmisten kasvokkaista kohtaamista tarvitaan. Kuntoutuksen perusrakenne muodostuu fyysisistä, sosiaalisista ja digitaalisista vuorovaikutuksen kentistä.

Sote-palveluiden uudistamiseen tarvitaan insentiivejä ja rakenteita, joilla innovointi mahdollistetaan. Kiinnostavia käytäntöjä ovat vaikuttavuuden ostot perinteisten suoritteiden hankintojen sijaan. Monissa Euroopan maissa on myös erityisasema yleishyödyllisille organisaatioille, joilta voidaan hankkia palveluita ilman kilpailutusta. Ehkä kumppanuusajattelu ennemmin kuin tiukat hankintakriteerit ja hinnan painottaminen mahdollistaa innovaatioiden syntymisen?

Vaikuttavuuden hankinnat ja vaikuttavuusinvestoinnit siirtävät ostajan ja tuottajan fokuksen suoritteista - kuntoutuspäivistä, erikoislääkärin konsultaatioista tai fysioterapeutin vetämistä keppijumpista - vaikutuksiin. Vaikutukset ovat esimerkiksi ihmisten työllistymistä ja elämänhallintaloikkaa.

Vaikuttavuus kiinnostaa myös asiakkaita. On todennäköistä, että asiakkaat hakeutuvat sellaisten palvelutuottajien palveluihin, joissa kuntoutus on vaikuttavaa. Vaikuttavuuden mittaaminen ja osoittaminen tulevat olemaan iso haaste ja mahdollisuus suomalaiselle palvelujärjestelmälle.

Soile Kuitunen, VTT, toimitusjohtaja,

Kuntoutussäätiö 